\title{
Penerapan Metode Analytical Hierarchi Process (AHP) Dalam Menentukan Tingkat Kerentanan Stunting (Gizi Buruk) Desa Di Kecamatan Juhar
}

Juliansen Saragih $^{1 *}$, Agustina Simangunsong ${ }^{2}$

${ }^{1,2}$ STMIK Pelita Nusantara

Jl. Iskandar Muda No. 1 Medan 20154

Corresponding author`s e-mail: ansen.saragih@yahoo.com

\begin{abstract}
Abstrak - Pada bulan Februari telah dilaksanakan pengukuran berat badan dan tinggi badan pada anak kelahiran tahun 2016-2020 di 25 desa. Pendataan yang dilakukan petugas Kecamatan Juhar, hanya berdasarkan Tinggi Badan (TB) dan Berat Badan (BB), kedua kriteria ini belum mewakili penentuan seorang anak rentan terhadap stunting mengingat beberapa ciri penyebab stunting lainnya. Penentuan tingkat kerentanan terhadap stunting dapat dikaji dengan menggunakan Sistem Pendukung Keputusan metode Analitycal Hierarchy Process (AHP).Dalam penelitian ini data kriteria faktor penyebab stunting meliputi layanan kesehatan, pola hidup sehat, pernikahan dini, kondisi geografis, ketersediaan pangan, infeksi penyakit, asupan gizi, dan pola asuh anak. menyajikan penelitian sebelumnya secara lugas dan komprehensif. rumusan masalah dalam penelitian ini menerapkan metode Analytical Hierarchi Process (AHP) dalam menentukan tingkat kerentanan stunting (gizi buruk) di Kecamatan Juhar. Seberapa besar hasil penerapan metode AHP dalam menetukan tingkat kerentanan stunting (gizi buruk) di Kecamatan Juhar. merancang dan membangun sistem keputusan dengan metode Analytical Hierarchi Process (AHP) dalam menentukan tingkat kerentanan stunting (gizi buruk) di Desa pada Kecamatan Juhar berbasis pemograman web.
\end{abstract}

Kata kunci: Tingkat Stunting, Hirarki, SPK, AHP

Abstract - In February, measurements of weight and height of children born in 2016-2020 were carried out in 25 villages. The data collection conducted by Juhar District officers was only based on height (TB) and weight (BB), these two criteria did not represent the determination of a child susceptible to stunting considering several other causes of stunting. Determination of the level of vulnerability to stunting can be studied using a Decision Support System with the Analytical Hierarchy Process (AHP) method. , and parenting styles. presents previous research in a straightforward and comprehensive manner. The formulation of the problem in this study applies the Analytical Hierarchy Process (AHP) method in determining the level of stunting vulnerability (malnutrition) in Juhar District. How big is the result of applying the AHP method in determining the level of vulnerability to stunting (malnutrition) in Juhar District. designing and building a decision system using the Analytical Hierarchy Process (AHP) method in determining the level of stunting vulnerability (malnutrition) in the village of Juhar District based on web programming.

Keywords: Stunting Level, Hierarchy, DSS, AHP

\section{Pendahuluan}

Saat ini stunting menjadi permasalahan yang sangat perlu diperhatikan. Indonesia memiliki tingat prevalensi stunting tinggi. Menurut data Riset Kesehatan Dasar (Riskesdas) tahun 2018 angka prevalensi stunting tercatat 8,7 juta $(30,7 \%)$ bayi berumur bawah lima tahun (balita) mengalami stunting [1]. Kendala pelaksanaan penurunan stunting disebabkan belum tersedianya strategi komprehensif. Stunting berhubungan dengan status gizi seorang anak yang stagnan, terkait dengan pola hidup bersih dan sehat, ada pernikahan dini, kondisi geografis dan akses ke layanan kesehatan yang sulit, dan potensi kerawanan pangan. Kerentanan (vulnerability) menunjukkan kondisi-kondisi, faktor-faktor atau proses-proses fisik, sosial, ekonomi, dan lingkungan yang meningkatkan kecenderungan (susceptibility) sebuah komunitas terhadap dampak bahaya [2].

Stunting merupakan salah satu kasus malnutrisi kronis yang prevalensinya terus meningkat dari tahun ke tahun di Indonesia [3]. Stunting digambarkan status gizi dengan tinggi badan menurut umur yang kurang dari standar pertumbuhan balita normal, yaitu kurang dari -2.0 standar deviasi. Stunting merupakan dampak dari beberapa faktor risiko, antara lain adalah rendahnya ketahanan pangan tingkat keluarga, hygiene sanitasi yang tidak baik, asupan makanan yang tidak tercukupi, dan beberapa determinan sosial. Dampak stunting, antara lain adalah dapat menyebabkan rendahnya kemampuan kognitif motorik dan meningkatkan beberapa risiko penyakit degenerative [4]. Sistem Pendukung Keputusan (SPK) atau Decision Support System (DSS) merupakan pengambilan keputusan dalam situasi semi terstruktur dan tidak terstruktu. SPK menyediakan informasi, membimbing, memberikan prediksi serta mengarahkan kepada pengguna informasi agar dapat 
melakukan pengambilan keputusan dengan lebih baik [5]. Analitycal Hierarchy Process (AHP) merupakan suatu model pendukung keputusan yang dikembangkan oleh Thomas L. Saaty. Model pendukung keputusan ini akan menguraikan masalah multi faktor atau multi kriteria yang kompleks menjadi suatu hirarki. Keputusan yang diambil didasarkan pada kriteria-kriteria yang menjadi pertimbangan. Pengambilan keputusan bermanfaat memberikan alternatif melalui tahapan membuat hirarki, penilaian kriteria dan alternatif, menentukan prioritas (synthesis of priority) dan konsistensi logis (logical consistency) [6].

Dalam penelitian ini data kriteria faktor penyebab stunting meliputi layanan kesehatan, pola hidup sehat, pernikahan dini, kondisi geografis, ketersediaan pangan, infeksi penyakit, asupan gizi, dan pola asuh anak. menyajikan penelitian sebelumnya secara lugas dan komprehensif. Rumusan masalah dalam penelitian ini menerapkan metode Analytical Hierarchi Process (AHP) dalam menentukan tingkat kerentanan stunting (gizi buruk) di Kecamatan Juhar. Seberapa besar hasil penerapan metode AHP dalam menetukan tingkat kerentanan stunting (gizi buruk) di Kecamatan Juhar. merancang dan membangun sistem keputusan dengan metode Analytical Hierarchi Process (AHP) dalam menentukan tingkat kerentanan stunting (gizi buruk) di Desa pada Kecamatan Juhar berbasis pemograman web. Batasan permasalahan penelitian penerapan metode Analytical Hierarchi Process (AHP) meliputi delapan desa se Kecamatan Juhar Kabupaten Karo yaitu Desa Pernantin (A1), Desa Sigenderang (A2), Desa Sukababo (A3), Desa Juhar Tarigan (A4), Desa Juhar Ginting Sadanioga (A5), Desa Buluh Pancur (A6), Desa Kidupen (A7), Desa Lau Lingga (A8). Data kriteria merupakan faktor penyebab terjadinya stunting meliputi layanan kesehatan, pola hidup sehat, pernikahan dini, kondisi geografis, ketersediaan pangan, infeksi penyakit, asupan gizi, dan pola asuh anak. Tingkat kerentanan terhadap stunting dalam penelitian ini sebagai sub kriteria, terbagi dalam kelompok rendah, sedang dan tinggi [7]. Tujuan penelitian adalah menerapkan metode AHP dalam menentukan tingkat kerentanan stunting berdasarkan data kriteria dan data alternatif. Membantu pengambil keputusan dalam menentukan tingkat kerentanan stunting di Kecamatan Juhar. Membatu dalam menetapkan desa yang tertinggi stunting sehingga dapat dilakukan penanganan yang lebih intens [8].

Penelitian Penerapan Metode Analytical Hierarchy Process (AHP) Pada Aplikasi Pendukung Keputusan Seleksi Karyawan Unicharm Indonesia menguraiakan aplikasi pendukung keputusan yang akan membantu staff HRD dalam melakukan pengelolaan data calon karyawan dan menyediakan informasi calon karyawan yang memenuhi kriteria dalam tahap seleksi karyawan [9]. Penelitian Sistem Pendukung Keputusan Untuk Mendiagnosa Gizi Buruk Ibu Hamil Menggunakan Metode AHP menguraikan masalah multi faktor atau multi kriteria yang kompleksmenjadi suatu hirarki. Penelitian Sistem Decision Support System Peningkatan Efektifitas Asupan Gizi Ibu Hamil menjelaskan dikategorikan kasus multikriteria. Metode pengambilan keputusan multikriteria yaitu Analytical Hierarchy Process (AHP), faktor-faktor yang mempengaruhi pengambilan keputusan dianalisa dalam struktur permasalahan berjenjang dengan menilai dan membuat ranking alternatif keputusan [10].

\section{Tinjauan Pustaka}

\subsection{Sistem}

Sistem dapat didefinisikan dengan pendekatan prosedur dan pendekatan komponen. Dengan pendekatan prosedur, sistem dapat didefinisikan sebagai kumpulan dari prosedur-prosedur yang mempunyai tujuan tertentu [11]. Sedangkan dengan pendekatan komponen, sistem dapat didefinisikan sebagai kumpulan dari komponen yang saling berhubungan satu dengan yang lainnya membentuk satu kesatuan untuk mencapai tujuan tertentu [12]. Terdapat tiga macam keputusan, yang biasanya dibayangkan oleh banyak orang bahwa keputusan sebagai keputusankeputusan yang sudah ada dalam suatu deretan langkah dari terstruktur ke tidak terstruktur [13]:

1. Keputusan terstruktur adalah suatu keputusan, semua atau sebagian besar dari variabel-variabel yang ada diketahui dan bisa diprogram secara total. Keputusan yang terstruktur bersifat rutin dan memerlukan sedikit pendapat manusia begitu variabel-variabel tersebut diprogram.

2. Keputusan tidak terstruktur adalah keputusan yang tetap resistan terhadap komputerisasi dan tergantung sepenuhnya pada intuisi.

3. Keputusan semi terstruktur adalah keputusan yang bisa diprogramkan sebagian namun masih memerlukan pendapat manusia.

Sistem Pendukung Keputusan (SPK) adalah suatu sistem yang digunakan untuk membantu mempercepat dan mempermudah proses pengambilan keputusan [14]. Tujuannya adalah untuk membantu pengambilan keputusan dalam memilih berbagai alternatif keputusan yang merupakan hasil pengolahan informasi yang diperoleh dengan menggunakan model mengambil keputusan.

\subsection{Metode Analytic Hierarchy Process (AHP)}


Metode Analytic Hierarchy Process (AHP) merupakan salah satu metode dalam sistem pendukung keputusan yang memiliki keunikan dibandingkan yang lainnya. Hal ini dikarenakan dalam pembobotan kriteria, bobot dari setiap kriteria bukan ditentukan diawal tetapi ditentukan dengan menggunakan rumus dari metode berdasarkan skala prioritas (tingkat kepentingan) yang bersumber dari tabel saaty. Metode ini merupakan metode yang sifatnya persepsional, artinya tingkat kepentingan dari suatu kriteria alternatif tergantung sudut pandang atau perspektif seseorang dalam menilainya. AHP merupakan suatu metode pendukung keputusan yang dikembangkan oleh seorang professor matematika University of Pittsburgh kelahiran Irak, Thomas L. Saaty [15]. AHP merupakan metode untuk membuat urutan alternatif keputusan dan pemilihan alternatif terbaik pada saat pengambil keputusan dengan beberapa tujuan atau kriteria untuk mengambil keputusan tertentu. Hal yang paling utama dalam AHP adalah hierarki fungsional dengan input utamanya persepsi manusia. Dengan hierarki, suatu masalah yang kompleks dan tidak terstruktur dapat dipecahkan ke dalam kelompoknya. Dalam menyelesaikan permasalahan dengan Analytical Hierarchy Process (AHP) ada beberapa prinsip yang harus dipahami :

1. Decomposition (Membuat Hirarki)

Sistem yang kompleks bisa dipahami dengan memecahkannya menjadi elemen-elemen pendukung, menyusun elemen secara hierarki, dan menggabungkannya atau mensintesisnya.

2. Comparative Judgement (Penilaian Kriteria dan Alternatif)

Kriteria dan alternatif dilakukan dengan perbandingan berpasangan. Nilai dan defenisi pendapat kualitatif dari skala perbandingan bisa diukur menggunakan tabel analisis seperti ditunjukan pada tabel 1.

Tabel 1. Skala Penilaian Perbandingan Pasangan

\begin{tabular}{|c|l|}
\hline $\begin{array}{c}\text { Intensitas } \\
\text { Kepentingan }\end{array}$ & \multicolumn{1}{c|}{ Keterangan } \\
\hline 1 & Kedua elemen sama pentingnya \\
\hline 3 & Elemen yang satu sedikit lebih penting daripada elemen yang lainnya \\
\hline 5 & Elemen yang satu lebih penting daripada elemen lainnya \\
\hline 7 & Satu elemen jelas lebih mutlak penting daripada elemen lainnya \\
\hline 9 & Satu elemen mutlak penting daripada elemen lainnya \\
\hline $2,4,6,8$ & Nilai-nilai antara dua nilai perbandingan yang berdekatan \\
\hline Kebalikan & $\begin{array}{l}\text { Jika aktivitas I mendapat satu angka dibandingkan dengan aktivitas I, maka I } \\
\text { memiliki nilai kebalikannya dibandingkan dengan I }\end{array}$ \\
\hline
\end{tabular}

3. Synthesis of priority (Menentukan Prioritas)

Sumber : Utama, D. N. (2017: 19)

Setiap kriteria dan alternatif, perlu dilakukan perbandingan berpasangan (Pairwise Comparisons). Nilainilai perbandingan relatif dari seluruh alternatif kriteria bisa disesuaikan dengan judgement yang telah ditentukan untuk menghasilkan bobot dan prioritas. Bobot dan prioritas dihitung dengan memanipulasi matriks atau melalui penyelesaian persamaan matematika.

4. Logical Consistency (Konsistensi Logis)

Konsistensi memiliki dua makna. Pertama yaitu objek-objek yang serupa bisa dikelompokkan sesuai dengan jenisnya. Kedua, menyangkut tingkat hubungan antar objek yang didasarkan pada kriteria tertentu.

\section{Metode Penelitian}

Berikut tahapan kerangka kerja penelitian :

1. Identifikasi Masalah

Identifikasi masalah dalam penelitian ini yaitu adanya permasalahan dalam penentuan tingkat kerentanan stunting di Kecamatan juhar, Kabupaten Karo. Permasalahan yang muncul di beberapa desa di Kecamatan Juhar, adanya penderita stunting yang menunjukkan gangguan tumbuh kembang anak yang disebabkan kekurangan asupan gizi, terserang infeksi, maupun stimulasi yang tak memadai.

2. Pengolahan Data

Data-data yang diperlukan untuk membangun sistem penentuan stunting diperoleh dari berbagai data yaitu data primer dan data sekunder. Studi literatur dilakukan dengan mengumpulkan informasi dari buku-buku, artikel, majalah yang berkaitan dengan masalah dan tujuan penelitian. Teknik ini dilakukan dengan tujuan untuk mengungkapkan berbagai teori-teori yang relevan dengan permasalahan yang sedang dihadapi/diteliti sebagai bahan rujukan dalam pembahasan hasil penelitian. Pengumpulan data dilakukan untuk memperoleh informasi yang dibutuhkan dalam rangka mencapai tujuan penelitian. Proses pengumpulan data ditentukan 
oleh variabel-variabel yang ada dalam hipotesis. Pengumpulan data dilakukan terhadap sampel yang telah ditentukan sebelumnya.

3. Penerapan Metode AHP

AHP merupakan metode memecah permasalahan yang komplek/ rumit dalam situasi yang tidak terstruktur menjadi bagianbagian komponen. Mengatur bagain atau variabel yang ada menjadi suatu bentuk susuna hierarki, kemudian memberikan nilai numerik dari setiap variabel dan mensitetis penilaian untuk variabel mana yang memiliki prioritas tertinggi yang akan mempengaruhi penyelesaian dari situasi tersebut. AHP menggabungkan pertimbangan dan penilaian pribadi dengan cara yang logis dan dipengaruhi imajinasi, pengalaman, dan pengetahuan untuk menyusun hierarki dari suatu masalah yang berdasarkan logika, intuisi dan juga pengalaman untuk memberikan pertimbangan. AHP merupakan suatu proses mengidentifikasi, mengerti dan memberikan perkiraan interaksi sistem secara keseluruhan. Tahapan penyelesaikan persoalan dengan menggunakan metode AHP, yaitu Decompotion, Comparative Judgement, Synthesis of priority dan Consistency.

4. Perancangan Sistem

Tahap ini membahas tentang perancangan dari model sistem dengan menentukan rancangan basisdata, prosedur dan perancangan antarmuka. Perancangan dalam sistem terdiri dari :

a. Perancangan Basisdata

Perancangan basis data merupakan hasil dari analisa data, yang selanjutnya pada bagian ini akan dibuat suatu perancangan tabel secara utuh dan lengkap dengan berbagai komponennya.

b. Perancangan Penerapan Metode AHP

c. Perancangan ini dilakukan untuk memberikan gambaran mengenai metode AHP yang diimplementasikan.

d. Perancangan Antarmuka

Perancangan antarmuka dilakukan untuk menggambarkan aplikasi yang akan dibangun sesuai dengan kebutuhan pengguna yang nantinya akan diimplementasikan menggunakan bahasa pemrograman.

5. Pengujian Sistem

Pada tahap pengujian sistem ini untuk melakukan pengujian terhadap sistem tersebut, mencari adakah kesalahan atau error yang masih ada di sistem, untuk selanjutnya diperbaiki sehingga bisa membantu dalam pihak terkait.

6. Implementasi

Implementasi merupakan tahap penerapan hasil rancangan yang telah dilakukan sebelumnya kedalam bentuk aplikasi dengan pemrograman berbasis web dan database $M y S q l$.

\section{Hasil dan Pembahasan}

Konsep dasar dari AHP adalah penggunaan pairwise comparison matrix (matriks perbandingan berpasangan) untuk menghasilkan bobot relatif antar kriteria maupun alternatif[16]. Penerapan metode AHP (Analytical Hierarcy Proces) dalam pemecahan masalah berkaitan dengan struktur yang berhierarki, sebagai konsekuensi dari kriteria yang dipilih, sampai pada sub kriteria yang paling dalam dengan perhitungan dan validitas sampai dengan batas toleransi inkonsistensi sebagai kriteria dan alternatif yang dipilih oleh pengambil keputusan.

Kegiatan dalam analisis data adalah mengelompokkan data berdasarkan variabel dan jenis responden, mentabulasi data berdasarkan variabel dari seluruh responden, menyajikan data dari tiap variabel yang diteliti, melakukan perhitungan untuk menjawab rumusan masalah, dan melakukan perhitungan untuk menguji hipotesis yang telah diajukan. Sekitar bulan Februari 2021 pemerintah Kecamatan Juhar melaksanakan pengukuran berat badan (BB) dan Tinggi Badan (TB) untuk anak kelahiran tahun 2016-2020. Sumber data dari Kantor Camat Juhar, diperoleh 8 desa yang mempunyai total stunting tinggi. Data kriteria digunakan sebagai acuan/dasar dari penilaian.

Tabel 2. Data Alternatif

\begin{tabular}{|c|l|l|}
\hline No & Kode & \multicolumn{1}{|c|}{ Alternatif } \\
\hline 1 & A1 & Desa Pernantin \\
\hline 2 & A2 & Desa Sigenderang \\
\hline 3 & A3 & Desa Sukababo \\
\hline 4 & A4 & Desa Juhar Tarigan \\
\hline 5 & A5 & Desa Juhar Ginting Sadanioga \\
\hline 6 & A6 & Desa Buluh Pancur \\
\hline 7 & A7 & Desa Kidupen \\
\hline 8 & A8 & Desa Lau Lingga \\
\hline
\end{tabular}


Tabel 3. Data Kriteria

\begin{tabular}{|c|l|l|}
\hline No & Kode & \\
\hline 1 & K1 & Layanan Kesehatan \\
\hline 2 & K2 & Pola Hidup Sehat \\
\hline 3 & K3 & Pernikahan Dini \\
\hline 4 & K4 & Kondisi Geografis \\
\hline 5 & K5 & Ketersediaan Pangan \\
\hline 6 & K6 & Infeksi Penyakit \\
\hline 7 & K7 & Asupan Gizi \\
\hline 8 & K8 & Pola Asuh Anak \\
\hline
\end{tabular}

Pembobotan kriteria dan sub kriteria penentuan stunting sebagai berikut :

1. Layanan kesehatan, akses keluarga dalam menerima informasi kesehatan dan pemanfaatan tempat pelayanan kesehatan yang ada dalam hal perawatan, penanganan masalah kesehatan keluarga terutama masalah kesehatan anak rumah sakit, puskesmas, bidan, dan tenaga serta pelayanan kesehatan formal.

Tabel 4. Karakteristik Layanan kesehatan

\begin{tabular}{|c|l|l|c|}
\hline No & Penilaian & \multicolumn{1}{|c|}{ Keterangan } & Skor \\
\hline 1 & Tinggi & $\begin{array}{l}\text { 1. Tersedianya Pustu } \\
\text { 2. Tersedianya Bidan desa } \\
\text { 3. Pelayanan Posyandu }\end{array}$ & 3 \\
\hline 2 & Sedang & Terdapat 2 karakteristik yang terpenuhi & 2 \\
\hline 3 & Rendah & Terdapat 1 atau tidak ada karakteristik yang terpenuhi & 1 \\
\hline
\end{tabular}

2. Pola Hidup Sehat, usaha menjaga lingkungan agar tetap bersih hingga pola makan seimbang.

Tabel 5 Karakteristik Pola Hidup Sehat

\begin{tabular}{|c|l|l|c|}
\hline No & Penilaian & \multicolumn{1}{|c|}{ Keterangan } & Skor \\
1 & Tinggi & $\begin{array}{l}\text { 1.Tersedianya MCK } \\
\text { 2. Tersedianya Sanitasi Lingkungan } \\
\text { 3. Air Bersih }\end{array}$ & 3 \\
\hline 2 & Sedang & Terdapat 2 karakteristik yang terpenuhi & 2 \\
\hline 3 & Rendah & Terdapat 1 atau tidak ada karakteristik yang terpenuhi & 1 \\
\hline
\end{tabular}

3. Pernikahan Dini, pernikahan dini menjadi salah satu penyebab terjadinya stunting, karena dengan pernikahan dini itu ada diantaranya adalah kehamilan tidak diinginkan, sehingga pertumbuhan janin di dalam kandungan tidak bisa optimal.

Tabel 6 Karakteristik Pernikahan Dini

\begin{tabular}{|l|l|l|c|}
\hline No & \multicolumn{1}{|c|}{ Penilaian } & \multicolumn{1}{|c|}{ Keterangan } & Skor \\
\hline 1 & Tinggi & Pernikahan umur $\geq 17$ tahun & 3 \\
\hline 2 & Sedang & Pernikahan umur 15-16 tahun & 2 \\
\hline 3 & Rendah & Pernikahan umur 12-14 tahun & 1 \\
\hline
\end{tabular}

4. Kondisi Geografis, kondisi geografis akibat kekeringan yang berdampak minimnya pasokan air bersih, juga menjadi faktor penentu tingginya angka stunting di daerah ini.

Tabel 7 Karakteristik Kondisi Geografis

\begin{tabular}{|l|l|l|c|}
\hline No & Penilaian & Keterangan & Skor \\
\hline 1 & Tinggi & Curah hujan tinggi & 3 \\
\hline 2 & Sedang & Curah hujan sedang & 2 \\
\hline 3 & Rendah & Curah hujan rendah & 1 \\
\hline
\end{tabular}

5. Ketersediaan Pangan, bayi usia 6-23 bulan dalam keluarga dengan ketersediaan pangan rawan memiliki risiko 2,7 kali lipat mengalami stunting dibandingkan dengan bayi dalam keluarga dengan ketersediaan pangan berkelanjutan. 
Tabel 8 Karakteristik Ketersediaan Pangan

\begin{tabular}{|l|l|l|c|}
\hline No & Penilaian & Keterangan & Skor \\
\hline 1 & Tinggi & Makan 3 x sehari & 3 \\
\hline 2 & Sedang & Makan 2 x sehari & 2 \\
\hline 3 & Rendah & Makan 1 x sehari & 1 \\
\hline
\end{tabular}

6. Infeksi Penyakit, kejadian ISPA, diare dan BBLR pada anak berkontribusi terhadap kejadian stunting.

Tabel 9. Karakteristik Infeksi Penyakit

\begin{tabular}{|l|l|l|c|}
\hline No & Penilaian & Keterangan & Skor \\
\hline 1 & Tinggi & Jumlah Penderita $\leq 50$ & 3 \\
\hline 2 & Sedang & Jumlah Penderita 50 - 100 & 2 \\
\hline 3 & Rendah & Jumlah Penderita $\geq 100$ & 1 \\
\hline
\end{tabular}

7. Asupan Gizi, Asupan energi yang kurang dapat menyebabkan ketidakseimbangan negatif akibatnya berat badan lebih rendah dari normal atau ideal.

Tabel 10. Karakteristik Asupan Gizi

\begin{tabular}{|l|l|l|c|}
\hline No & Penilaian & Keterangan & Skor \\
\hline 1 & Tinggi & Jumlah Penderita Obesitas $\leq 50$ & 3 \\
\hline 2 & Sedang & Jumlah Penderita Obesitas 50 - 100 & 2 \\
\hline 3 & Rendah & Jumlah Penderita obesitas $\geq 100$ & 1 \\
\hline
\end{tabular}

8. Pola Asuh Anak Usia 0-12 bulan, stunting juga dipengaruhi aspek perilaku, terutama pada pola asuh yang kurang baik dalam praktek pemberian makan bagi bayi dan balita.

Tabel 11. Karakteristik Pola Asuh Anak

\begin{tabular}{|c|c|c|c|}
\hline No & Penilaian & Keterangan & Skor \\
\hline 1 & Tinggi & $\begin{array}{l}\text { 1. Stimulasi } \\
\text { 2. ASI } \\
\text { 3. MPASI }\end{array}$ & 3 \\
\hline 2 & Sedang & Terdapat 2 karakteristik yang terpenuhi & 2 \\
\hline 3 & Rendah & Terdapat 1 atau tidak ada karakteristik yang terpenuhi & 1 \\
\hline
\end{tabular}

LambdaMax $(\lambda \max )$. $\lambda \max$ diperoleh dari Jumlah rata-rata Baris Total Matriks Perbandingan Berpasangan per kolom dikali bobot prioritas. Jumlah rata-rata Baris Total Matriks Perbandingan Berpasangan per kolom adalah K1 $=0.215980 \mathrm{~K} 2=0.189010 \mathrm{~K} 3=0.095683 \mathrm{~K} 4=0.126513 \mathrm{~K} 5=0.089920 \mathrm{~K} 6=0.098955$ $\mathrm{K} 7=0.095899 \mathrm{~K} 8=0.088036 . \lambda \max =9.542546292$. Nilai CI (Consistency Index). $\mathrm{CI}=(\lambda \max -\mathrm{n}) / \mathrm{n}$; keterangan $: \mathrm{n}=$ banyaknya elemen atau kriteria. $\lambda \max =\mathrm{n}$ adalah jumlah kriteria (ukuran matriks) $=8$, sehingga Jumlah (jumlah kolom hasil) $=9.542546292$. Jumlah kriteria $\mathrm{n}=8$. Nilai CI $((\lambda$ maks $-\mathrm{n}) / \mathrm{n})=$ $((1.19281829-8) / 8)=-0.85089771$. Rasio konsistensi / Consistency Ratio (CR). CR = CI/RC. Matriks terdiri dari 8 kriteria maka otomatis RI = 1.41, Nilai CR $(C I / I R)=-0.85089771 / 1.41=-0.603473556$, nilai IR lihat tabel Karena nilai CR $(-0.603473556)<0.1$, maka dapat dikatakan bahwa rasio konsistensi dari perhitungan diterima. Memeriksa konsistensiCR/IR $=-0.603473556$ maka hasil perhitungan konsisten.

Tabel 12. Nilai Eigen Alternatif A8

\begin{tabular}{|c|c|c|c|c|c|c|c|c|c|c|}
\hline & A1 & A2 & A3 & A4 & A5 & A6 & A7 & A8 & Jumlah & Bobot Prioritas \\
\hline A1 & 0.143 & 0.203 & 0.100 & 0.158 & 0.136 & 0.095 & 0.200 & 0.100 & 1.1360 & 0.1420 \\
\hline A2 & 0.071 & 0.102 & 0.300 & 0.052 & 0.136 & 0.190 & 0.100 & 0.100 & 1.0522 & 0.1315 \\
\hline A3 & 0.143 & 0.034 & 0.100 & 0.158 & 0.136 & 0.095 & 0.100 & 0.100 & 0.8661 & 0.1083 \\
\hline A4 & 0.143 & 0.305 & 0.100 & 0.158 & 0.136 & 0.095 & 0.200 & 0.200 & 1.3377 & 0.1672 \\
\hline A5 & 0.143 & 0.102 & 0.100 & 0.158 & 0.136 & 0.286 & 0.100 & 0.100 & 1.1247 & 0.1406 \\
\hline A6 & 0.143 & 0.051 & 0.100 & 0.158 & 0.045 & 0.095 & 0.100 & 0.200 & 0.8920 & 0.1115 \\
\hline A7 & 0.071 & 0.102 & 0.100 & 0.079 & 0.136 & 0.095 & 0.100 & 0.100 & 0.7838 & 0.0980 \\
\hline A8 & 0.143 & 0.102 & 0.100 & 0.079 & 0.136 & 0.048 & 0.100 & 0.100 & 0.8076 & 0.1010 \\
\hline
\end{tabular}

Bobot Prioritas akhir diperoleh dari jumlah rata-rata bobot prioritas kriteria-kriteria setiap alternatif. 


\begin{tabular}{|c|c|c|c|c|c|c|c|c|c|}
\hline \multicolumn{10}{|c|}{ Tabel 13. Hasil Prioritas Akhir } \\
\hline Data Alternatif & K1 & $\mathrm{K} 2$ & K3 & K4 & K5 & K6 & K7 & K8 & Prioritas Akhir \\
\hline Desa Pernantin A1 & 0.64 & 0.27 & 1.0 & 0.64 & 0.64 & 1.0 & 1.0 & 1.0 & 6.18 \\
\hline Desa Sigenderang A2 & 0.27 & 0.64 & 0.64 & 0.64 & 0.64 & 0,27 & 0,64 & 0,27 & 3,99 \\
\hline Desa Sukababo A3 & 0.27 & 0.64 & 0.27 & 0.64 & 0.27 & 0.64 & 0.27 & 1.0 & 3,99 \\
\hline Desa Juhar Tarigan A4 & 0.64 & 1.0 & 0.27 & 0.64 & 0.27 & 0.64 & 1.0 & 1.0 & 5.45 \\
\hline Desa Juhar Ginting Sadanioga A5 & 0.64 & 0.64 & 0.27 & 0.64 & 0.64 & 0.64 & 0.64 & 1.0 & 5.09 \\
\hline Desa Buluh Pancur A6 & 0.64 & 1.0 & 0.64 & 0.27 & 1.0 & 0.27 & 0.27 & 1.0 & 5.08 \\
\hline Desa Kidupen A7 & 0.27 & 0.64 & 0.64 & 0.64 & 0.64 & 1.0 & 1.0 & 0.64 & 5.45 \\
\hline Desa Lau Lingga A8 & 0.64 & 0.64 & 0.27 & 0.27 & 0.64 & 0.27 & 0.27 & 1.0 & 3.99 \\
\hline
\end{tabular}

Tabel 14. Skor Kriteria

\begin{tabular}{|c|c|c|c|c|c|c|c|c|}
\hline K1 & K2 & K3 & K4 & K5 & K6 & K7 & K8 & Skor \\
\hline Tinggi & Tinggi & Tinggi & Tinggi & Tinggi & Tinggi & Tinggi & Tinggi & 3 \\
\hline Sedang & Sedang & Sedang & Sedang & Sedang & Sedang & Sedang & Sedang & 2 \\
\hline Rendah & Rendah & Rendah & Rendah & Rendah & Rendah & Rendah & Rendah & 1 \\
\hline
\end{tabular}

Tabel 15. Penilaian Alternatif

\begin{tabular}{|l|l|l|l|l|l|l|l|l|l|}
\hline & \multicolumn{1}{|c|}{ K1 } & \multicolumn{1}{|c|}{ K2 } & \multicolumn{1}{|c|}{ K3 } & \multicolumn{1}{c|}{ K4 } & \multicolumn{1}{c|}{ K5 } & \multicolumn{1}{c|}{ K6 } & \multicolumn{1}{|c|}{ K8 } \\
\hline Desa Pernantin & Sedang & Tinggi & Rendah & Sedang & Sedang & Rendah & Rendah & Rendah \\
\hline Desa Sigenderang & Tinggi & Sedang & Sedang & Sedang & Sedang & Tinggi & Sedang & Tinggi \\
\hline Desa Sukababo & Tinggi & Sedang & Tinggi & Sedang & Tinggi & Sedang & Rendah & Rendah \\
\hline Desa Juhar Tarigan & Sedang & Rendah & Tinggi & Sedang & Tinggi & Sedang & Rendah & Rendah \\
\hline $\begin{array}{l}\text { Desa Juhar Ginting } \\
\text { Sadanioga }\end{array}$ & Sedang & Sedang & Tinggi & Sedang & Sedang & Sedang & Sedang & Rendah \\
\hline Desa Buluh Pancur & Sedang & Rendah & Sedang & Tinggi & Rendah & Tinggi & Tinggi & Rendah \\
\hline Desa Kidupen & Tinggi & Sedang & Sedang & Sedang & Sedang & Rendah & Rendah & Sedang \\
\hline Desa Lau Lingga & Sedang & Sedang & Tinggi & Tinggi & Sedang & Tinggi & Tinggi & Rendah \\
\hline
\end{tabular}

Setelah mendapatkan Bobot Prioritas akhir, langkah selanjutnya menentukan range dari setiap tingkat kerentanan.

Tabel 16. Data Range Penilaian

\begin{tabular}{|c|c|l|}
\hline Nilai & Tingkat Kerentanan & \multicolumn{1}{c|}{ Keterangan } \\
\hline$\leq 3.99$ & Tinggi & $\begin{array}{l}\text { Nilai Tinggi diperoleh sama dengan atau lebih kecil } \\
\text { dari 3.99 }\end{array}$ \\
\hline$\geq 4,00-5,99$ & Sedang & Nilai diperoleh antara 4,00 sampai 5,99 \\
\hline$\geq 6,00$ & Rendah & $\begin{array}{l}\text { Nilai Rendah diperoleh sama dengan atau lebih besar } \\
\text { dari 6.00 }\end{array}$ \\
\hline
\end{tabular}

Penentuan tingkat kerentanan stunting desa disimpulkan dari hasil Tabel data range penilaian. Semakin RENDAH $(\leq 3,99)$ nilai total bobot prioritas kriteria alternatif maka desa tersebut memiliki Tingkat Kerentanan yang TINGGI terhadap stunting dan sebaliknya total nilai TINGGI $(\geq 5,00)$ menunjukkan desa mempunyai tingkat kerentanan RENDAH terhadap stunting. Hasil akhir penentuan tingkat kerentanan stunting dengan menggunakan metode AHP diperoleh berdasarkan range nilai perkalian matriks antara matriks perbandingan dan vektor prioritas. Tingkat kerentanan desa-desa di Kecamatan Juhar terhadap stunting sebagai berikut :

a. Kerentanan Tinggi, Bobot Nilai $=\leq 3$ 3.99. Desa Sigenderang ( A2) ,Desa Sukababo (A3) dan Desa Lau Lingga (A8)

b. Kerentanan Sedang, Bobot Nilai 4,00 sampai 5,00. Desa Juhar Tarigan (A4), Desa Juhar Ginting Sadanioga (A5), Desa Buluh Pancur (A6), Desa Kidupen (A7).

c. Kerentanan Rendah, Bobot Nilai $=\geq 5$,00. Desa Pernantin (A1), Desa Juhar Tarigan (A4), Desa Juhar Ginting Sadanioga (A5), Desa Buluh Pancur (A6), Desa Kidupen (A7).

Halaman beranda pertama muncul ketika aplikasi diakses juga disebut halaman muka dari suatu situs web (web site), atau lokasi dari situs web untuk mengakses halaman awal tersedia menu Beranda dan Login (Masuk), Dashboard disediakan untuk membantu menampilkan atau memodelkan suatu hasil analisis dalam bentuk laporan grafis yang interaktif. Digital Dashboard menyediakan akses yang sangat mudah terhadap datadata yang dihasilkan dan dapat membantu menginformasikan serta mengoptimalkan akurasi pengambilan keputusan. Pada menu dashboard diinformasikan jumlah user, jumah desa dan jumlah pengunjung. Terdapat juga informasi mengenai stunting dan uraian gizi 


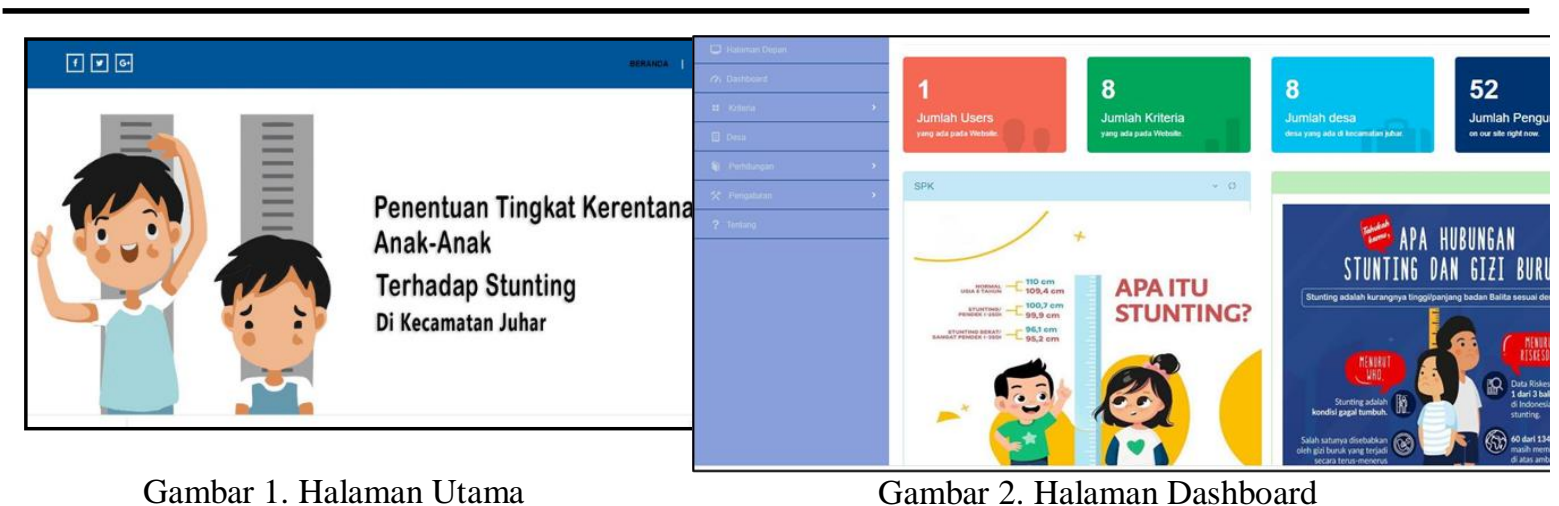

Gambar 1. Halaman Utama

Gambar 2. Halaman Dashboard

Pengukuran metode Analytical Hierarchical Process (AHP) digunakan untuk menentukan skala rasio dari perbandingan pasangan yang diskrit maupun kontinu, yang diperoleh dari ukuran aktual ataupun preferensi dengan mencari baris total tiap kolom kriteria. Baris total diperoleh dengan menjumlahkan masing masing baris dari setiap kolom.

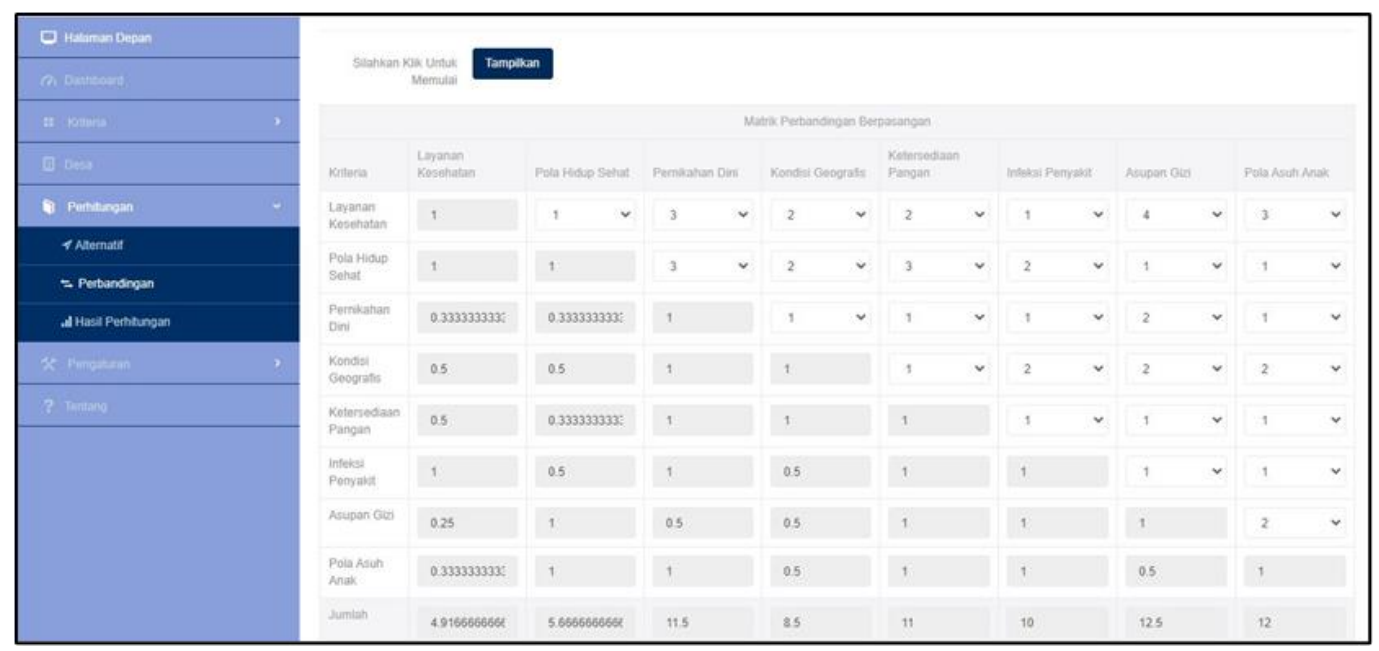

Gambar 3. Tampilan Perhitungan

\section{Kesimpulan}

Kesimpulan dari penelitian :

1. Sistem mampu memberikan alternatif dalam pengambilan keputusan, berdasarkan penerapan metode Analytical Hierarchi Process (AHP).

2. Penentuan kerentanan desa-desa terhadap stunting (gizi buruk) dipengaruhi dari Kriteria dan Nilai Sub Kriteria tinggi sedang dan rendah.

3. Aplikasi menyediakan informasi tingkat kerentanan desa-desa terhadap stunting (gizi buruk) dengan dukungan perhitungan metode Analytical Hierarchi Process (AHP).

\section{Daftar Pustaka}

[1] A. Umiyah and A. Hamidiyah, "Karakteristik Anak Dengan Kejadian Stunting Characteristics of Children with Stunting," vol. 8, no. 1, pp. 66-72, 2021.

[2] J. Mustafa, S. No, T. Selatan, and J. K. Komunitas, "Permasalahan Anak Pendek ( Stunting ) dan Intervensi untuk Mencegah Terjadinya Stunting ( Suatu Kajian Kepustakaan ) Stunting Problems and Interventions to Prevent Stunting ( A Literature Review ),” vol. 2, no. 5, 2015.

[3] Y. Wardita, E. Suprayitno, and E. M. Kurniyati, "Determinan Kejadian Stunting pada Balita," vol. VI, no. I, pp. 7-12, 2021.

[4] Y. H. Siregar and S. Rahayu, "Sistem Pendukung Keputusan Pemilihan Menu Makanan bagi Anak dengan Metode Analitycal Hierarchy Process ( AHP )," vol. 2, no. 1, 2018.

[5] A. Sutrisno, J. Neyland, J. Teknik, M. Universitas, S. Ratulangi, and S. Cadang, "Penerapan Metode Ahp ( Analytical Hierarchy Process ) Untuk Pemilihan Supplier Suku Cadang Di,” vol. 6, pp. 32-44. 
[6] A. Suryadi and D. Nurdiana, "Teknisi Lab Dengan Multi Kriteria Menggunakan Metode Ahp ( Analytic Hierarchy Process )," vol. 5, no. April, 2015.

[7] J. S. Komputer et al., "Pemilihan Aplikasi Meeting Online Untuk Mendukung Work From Home Menggunakan Metode AHP," vol. 4, no. September, pp. 533-544, 2020.

[8] R. A. Suherdi, R. Taufiq, A. A. Permana, P. S. Informatika, F. Teknik, and U. M. Tangerang, "Penerapan metode ahp dalam sistem pendukung keputusan kenaikan pangkat pegawai di badan kepegawaian dan pengembagan sumber daya manusia kota tangerang," pp. 522-528, 2018.

[9] A. Herdiansah, "Sistem Pendukung Keputusan Referensi Pemilihan Tujuan Jurusan Teknik Di Perguruan Tinggi bagi Siswa Kelas XII IPA Mengunakan Metode AHP,” vol. 19, no. 2, pp. 223-234, 2020.

[10] P. Sistem and P. Mahasiswa, "Berprestasi Menggunakan Metode Ahp Berbasis Web ( Studi Kasus : Prodi Sistem Informasi Unipdu Jombang )," vol. 3, no. 1, pp. 80-89, 2020.

[11] J. J. Click, D. Amelia, S. Informasi, S. Jayanusa, J. Damar, and N. E. Padang, "JURNAL J - CLICK," pp. 196-203, 2020.

[12] S. Siswanti, F. L. Wrehatnala, and A. Kusumaningrum, "Penerapan Metode Analytical Hierarchy Process Dan Technique for Order Preference by Similarity to Ideal Solution Sebagai Pendukung Keputusan Dalam Menentukan Kenaikan Jabatan Bagi Guru," no. 1, pp. 35-48, 2020.

[13] A. S. R. Sinaga and J. Purba, "Penentuan Karyawan Lembur Dengan Metode Analytical Hierarchy Process ( Ahp )," vol. 1, no. 2, pp. 40-50, 2018.

[14] A. Sindar, R. M. Sinaga, M. Marbun, and A. S. Sitio, "Pengenalan Pemrograman Web Pada Karang Taruna Pemuda Pemudi Sejati Guna Mengembangkan Skill," vol. 5, no. 4, pp. 1631-1639, 2021.

[15] D. Lestari and A. S. R. Sinaga, "Penentuan Karyawan Kontrak Menjadi Karyawan Tetap PT. Timbang Deli Dengan Metode Analitycal Hierarchy Process (AHP),” J. Teknol., vol. 8, no. 2, pp. 27-37, 2018.

[16] L. Situmorang and J. R. Sagala, "Sistem Pendukung Keputusan Pemilihan Tentor Terbaik Dengan Metode Technique For Order Preference By Similarity To Ideal Solution (Topsis)," J. Nas. Komputasi dan Teknol. Inf., vol. 3, no. 3, pp. 209-214, 2020. 